\title{
Hyperbaric Oxygen Therapy for the Treatment of Fournier's Gangrene: A Review of 34 Cases
}

\author{
Oxigenoterapia Hiperbárica no Tratamento da Gangrena de Fournier: Revisão \\ de 34 Casos
}

\author{
Isabel ROSA 1 , Francisco GUERREIRO $\rrbracket^{1}$ \\ Acta Med Port 2015 Sep-Oct;28(5):619-623
}

\section{ABSTRACT}

Introduction: Fournier's gangrene is a serious necrotizing infection that can be fatal if not promptly attended. Treatment for this condition consists of a combination of surgical debridement, antibiotherapy and supportive care. Hyperbaric oxygen therapy is used as an adjuvant for the optimization of infected tissue oxygenation and for its bactericidal and bacteriostatic effects.

Material and Methods: The data presented in this study encompass a period of 25 years of clinical records of patients with Fournier's gangrene that had been treated at our center with hyperbaric oxygen therapy.

Results: A total of 34 patients were treated. The vast majority of patients were males $(94.1 \%)$ with a mean age of 53.7 years. Urinary tract was the most frequent source of infection and diabetes was most common comorbidity seen in patients. Mortality rate was $20.8 \%$. Discussion: The most common observed comorbidity was diabetes, suggesting diabetes as one predisposing factor. The majority of deceased patients had diabetes, although no significant correlation between diabetes and death was found. The area of residence of patients may affect patients' referral to these facilities.

Conclusions: Although Fournier's gangrene is a rare condition, it is nevertheless a fatal illness, namely in patients with comorbidities like diabetes. Hyperbaric oxygen therapy is recommended as an adjuvant to conventional therapy and should be considered whenever available. To further assess the role of hyperbaric oxygen therapy, in the treatment of this condition, additional studies should be carried out.

Keywords: Fournier Gangrene; Hyperbaric Oxygenation.

\section{RESUMO}

Introdução: A gangrena de Fournier é uma infecção necrotizante grave, que pode levar à morte se não for tratada rapidamente. $\mathrm{O}$ tratamento baseia-se na combinação do desbridamento cirúrgico, antibioterapia e terapêutica de suporte. A oxigenoterapia hiperbárica surge como adjuvante quer na optimização da oxigenação dos tecidos infetados, quer através da ação bactericida e bacteriostática.

Material e Métodos: Foi feita uma revisão dos processos clínicos dos doentes com gangrena de Fournier referenciados ao Centro de Medicina Subaquática e Hiperbárica da Marinha para realizar oxigenoterapia hiperbárica num período de 25 anos.

Resultados: Foram tratados 34 doentes. A maioria dos doentes era do género masculino $(94,1 \%)$ com idade média de 53,7 anos. A diabetes foi a comorbilidade mais frequentemente associada. O foco de infeção mais frequente foi o trato urinário. A taxa de mortalidade foi de $20,8 \%$.

Discussão: A diabetes é a comorbilidade mais frequente, sugerindo a diabetes como factor predisponente. A maioria dos doentes falecidos tinham diabetes, todavia não se conseguiu estabelecer correlação entre diabetes e morte. A área de residência dos doentes parece limitar a referenciação ao centro.

Conclusões: A gangrena de Fournier, apesar de rara, é uma doença potencialmente fatal, nomeadamente em doentes com comorbilidades como a diabetes. A oxigenoterapia hiperbárica está recomendada como adjuvante à terapêutica convencional e, quando este recurso está disponível, deve ser considerado. São necessários mais estudos para melhor aferir o papel da oxigenoterapia hiperbárica no tratamento desta entidade.

Palavras-chave: Gangrena de Fournier; Oxigenação Hiperbárica.

\section{INTRODUCTION}

Fournier's gangrene is a necrotizing fasciitis affecting the genital, perineal and perianal regions and characterized by a polymicrobial origin and for being a progressive disease. It was first described in 1883 by Jean Alfred Fournier, a dermatologist and venereologist, in 5 young and healthy males with an acute and rapidly progressive scrotum gangrene, with no apparent etiology. ${ }^{1}$

It is characterized by an obliterating endarteritis that leads to thrombosis of subcutaneous tissue blood vessels, ultimately leading to both skin and vessel gangrene..$^{1,2}$ It is a rare disease $e^{2,3}$ that predominantly affects males (at a 10 to 1 ratio) with an average age of 50 years. ${ }^{2,4}$
Several predisposing factors have been identified: diabetes, alcoholism, arterial hypertension, renal and hepatic insufficiency, obesity, dementia, tobacco consumption and diseases that affect the immune system such as human immunodeficiency syndrome (HIV), chemo and radiotherapy, cancer and surgical interventions. Concerning etiology, the source can be in the urogenital tract, anorectal region and skin infections. . $^{1,5,6}$

The therapeutic approach to a necrotizing soft tissue infection such as Fournier's gangrene requires a good coordination between surgeon and intensivist. Early surgical debridements are key to a successful treatment,

1. Centro de Medicina Subaquática e Hiperbárica da Marinha. Lisboa. Portugal.

$\triangle$ Autor correspondente: Francisco Guerreiro. quaresma.guerreiro@marinha.pt

Recebido: 08 de Fevereiro de 2015 - Aceite: 21 de Julho de 2015 | Copyright @ Ordem dos Médicos 2015 
complemented with large spectrum antibiotherapy and supportive care. ${ }^{1,7}$ Hyperbaric oxygen therapy (HBOT) is used as an adjuvant therapy. ${ }^{1,2,8}$

HBOT consists in the inhalation $100 \% \mathrm{O}_{2}$ in a pressurized environment - pressure superior to atmospheric pressure (ATM) at sea level - usually at 2 to 3 ATM.

According to the European Committee for Hyperbaric Medicine, HBOT is recommended for anaerobial or mixed bacterial infections (type 1 recommendation, evidence level C). ${ }^{9}$

HBOT has anti-infectious effects owing to several mechanisms, including: high $\mathrm{O} 2$ levels inside tissues that have bactericide and bacteriostatic effects over certain bacteria, especially in anaerobes; increased phagocytic activity and bacterial lysis by neutrophils; synergism with certain antibiotics is also observed. ${ }^{10,11}$

Several studies indicate that the use of HBOT in necrotizing soft tissue infections is associated with an increased survival. ${ }^{10,12-14}$

The therapeutic protocol ministered at our center consists of HBO sessions at 2.8 ATM for 90 minutes (Fig. 1 - top) twice daily until the infection is controlled (until
2011 the protocol was 90 minutes of HBO at 2.5 ATM twice daily) followed by HBO daily sessions at 2.5 ATM for 75 minutes until the condition is fully resolved (Fig. 1 - bottom). In this study, a review of 25 year experience of our center in treating Fournier's gangrene with HBOT is performed.

\section{MATERIAL AND METHODS}

This is a retrospective and descriptive study.

Clinical records of patients diagnosed with Fournier's gangrene treated with HBOT at Underwater Hyperbaric Medicine Center of the Portuguese Navy, from December 1989 to November 2014, were reviewed. The following parameters were assessed: demographics, etiology, co-morbidities, aggressive surgical debridement (fecal diversion and orchidectomy), microbiology, antibiotherapy, number of HBOT sessions and clinical outcomes.

\section{RESULTS}

A total of 34 cases of Fournier's gangrene were treated between December 1989 and November 2014. Patients were mainly from hospitals in Lisbon's metropolitan area. Four of those patients were from hospitals in the periphery
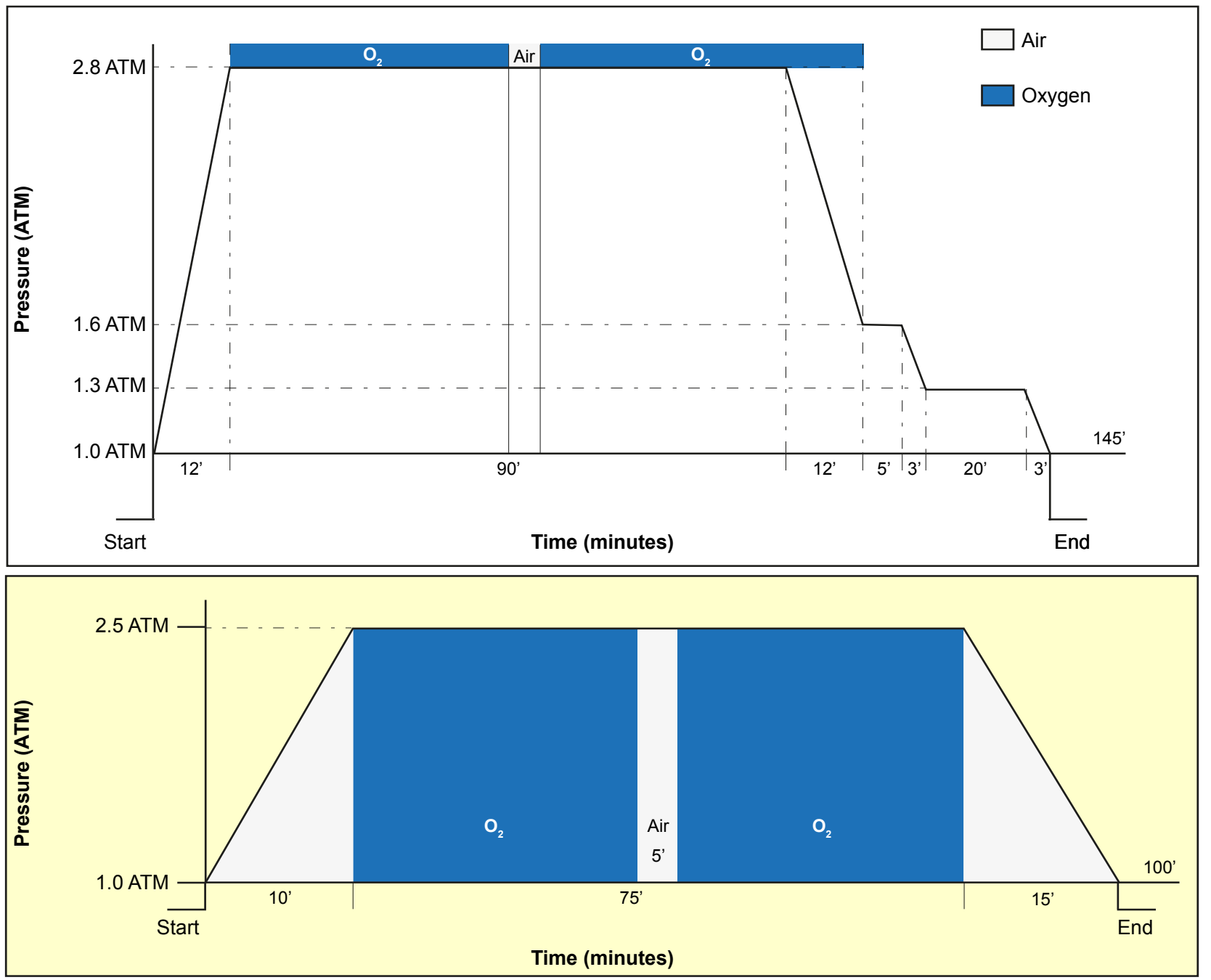

Figure 1 - Therapeutic protocol in gas gangrene advocates HBO at 2.8 ATM for 90 minutes, twice daily until sepsis is controlled (Top). At 2.5 ATM sessions, oxygen is administered for 75 minutes (Bottom). 
on a $100 \mathrm{~km}$ radius.

The mean age of patients was 53.7 years, with a minimum of 19 and a maximum of 82 years. Thirty-two were male $(94.1 \%)$ and two were female $(5.9 \%)$.

Of the 21 patients that presented co-morbidities, 13 (corresponding to $61.9 \%$ ) presented diabetes. Other comorbidities were observed and are presented in Table 1.

Regarding etiology, out of 18 patients, 7 cases (38.9\%) were derived from urinary tract conditions including prostate cancer, prostatitis and orchiepididymitis, 5 cases $(27.8 \%)$ had their origin in coloproctological diseases like rectal cancer (2 patients), acute diverticulitis (2 patients) and perianal abscess ( 1 patient) and 3 cases were classified as idiopathic (Table 2). Data was not available regarding etiology in the remaining 16 patients.

All patients underwent surgical debridement. In eight

\section{Table 1 - Comorbidities}

\begin{tabular}{lc}
\hline Comorbidities & $\begin{array}{c}\text { Number of } \\
\text { patients }\end{array}$ \\
\hline Diabetes & 13 \\
HIV & 1 \\
Alcoholism & 4 \\
Hepatic insufficiency & 1 \\
High blood pressure & 5 \\
Ischemic heart disease & 2 \\
Cancer & 3 \\
Obesity & 2 \\
Peripheral arterial disease & 1 \\
Others & 3 \\
$\geq 2$ comorbidities & 13 \\
\hline
\end{tabular}

Table 2 - Etiology

\begin{tabular}{lc}
\hline Etiology & $\begin{array}{c}\text { Number of } \\
\text { patients }\end{array}$ \\
\hline $\begin{array}{l}\text { Urological (prostate cancer, prostatitis } \\
\text { and orchiepididymitis) }\end{array}$ & 7 \\
$\begin{array}{l}\text { Rectal cancer (post chemo - and } \\
\text { radiotherapy) }\end{array}$ & 2 \\
Perianal abscess & 1 \\
Trauma & 2 \\
Acute diverticulitis & 2 \\
Suppurative hydrosadenitis & 1 \\
Idiopathic & 3 \\
\hline
\end{tabular}

patients $(23.5 \%)$, fecal diversion with colostomy was performed to prevent wound contamination and optimize bandage application. A patient underwent orchidectomy due to extensive surgical debridement.

In this retrospective work, we only found microbiological results in 4 patients, namely 2 with $\beta$-hemolytic Streptococcus, one with Klebsiella oxytoca and one with Acinetobacter spp.

The most commonly used antibiotics were: metronidazol, clindamycin, meropenem and gentamicin almost always in combination (Table 3). The most frequent antibiotic combinations were metronidazol + meropenem and gentamicin + clindamycin.

Out of the 24 patients of which there was information regarding their clinical evolution, $19(79.2 \%)$ survived and were discharged from the hospital and $5(20.8 \%)$ died. Of the patients that passed away, $4(80 \%)$ had been diagnosed with diabetes. After performing a bivariate analysis, no significant correlation (Pearson's correlation coefficient $r=-0.266$ with $p>0.05$, with $n=24$ ) was found between diabetes as comorbidity and death as outcome. We had no access to the clinical evolution of 10 patients.

Surviving patients performed an average of 22.4 sessions (with a standard deviation of 21.6), with a minimum of 6 and maximum of 100 sessions.

Table 3 - Used antibiotics

\begin{tabular}{lc}
\hline Antibiotic & $\begin{array}{c}\text { Number of } \\
\text { patients }\end{array}$ \\
\hline Metronidazol & 11 \\
Clindamycin & 7 \\
Meropenem & 7 \\
Gentamicin & 8 \\
Penicillin & 4 \\
Vancomycin & 1 \\
Netilmycin & 3 \\
Imipenem & 4 \\
Ceftriaxone & 1 \\
Flucloxacillin & 2 \\
Piperacillin + Tazobactam & 1 \\
Linezolide & 2 \\
Amikacin & 1 \\
Ciprofloxacin & 2 \\
Cotrimoxazol & 1 \\
\hline & 2 \\
\hline & 1
\end{tabular}



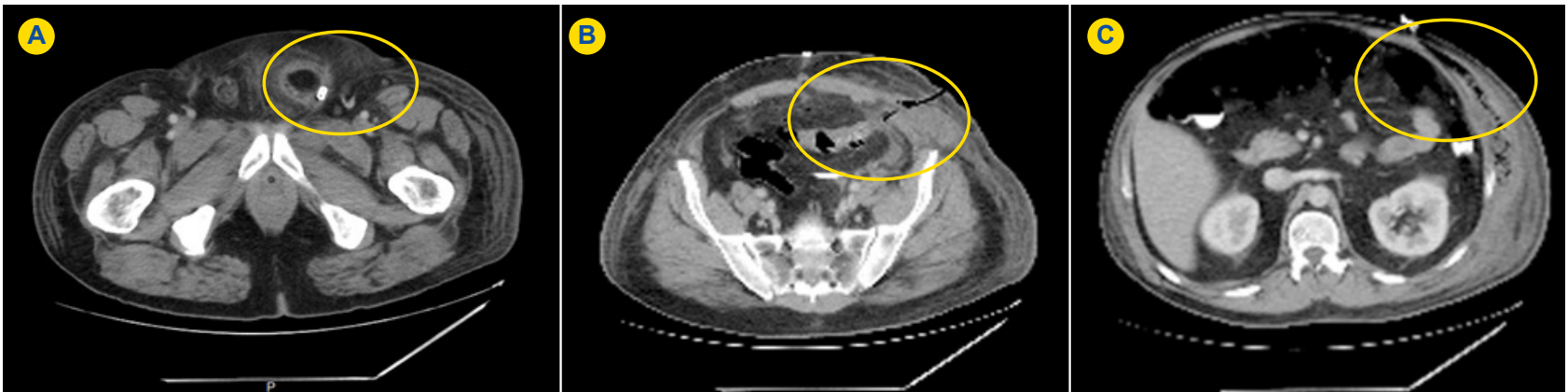

Figure 2 - Fournier's gangrene in a patient with acute diverticulitis, affecting left scrotum (A); pelvic area (B) and dissecting left abdominal wall $(C)$.
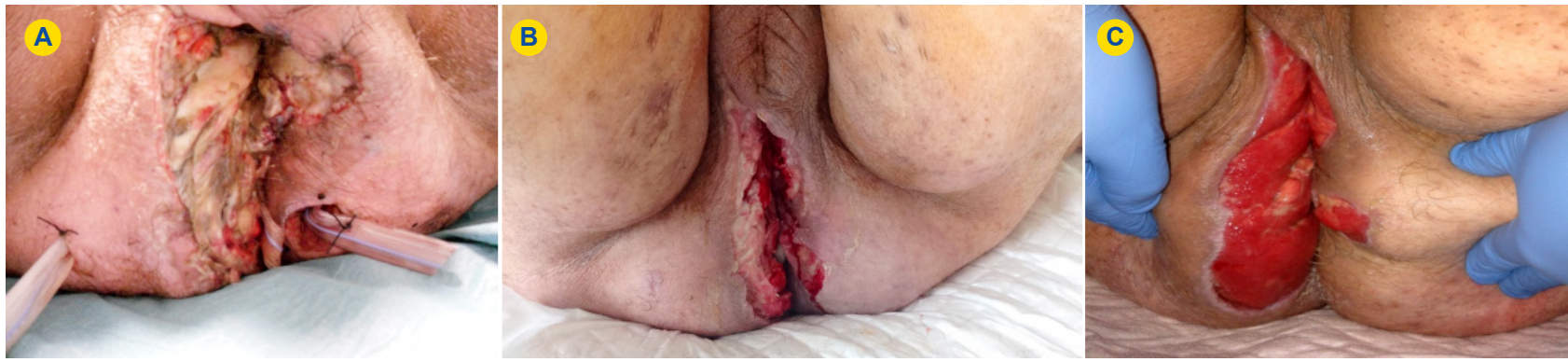

Figure 3 - Fournier's gangrene in the first HBOT session after drainage (A); after his tenth HBOT session (B) and after his twentieth session $(C)$

Fig. 2 shows computed tomography images of a patient with Fournier's gangrene after drainage. The patient presented at emergency department with fever, perineal and abdominal pain. It was found that acute diverticulitis was the origin of his condition.

Fig. 3 portrays a patient with Fournier's gangrene in his first HBOT session following drainage (A); after his tenth session (B) and after his twentieth session (C).

Complications related to HBOT were seen in 4 patients, namely middle ear barotrauma in one patient and anxiety in three patients.

\section{DISCUSSION}

It was found that the area of residence of patients may affect patients' referral to our center. Owing to the need for differential care and the logistics problems they pose, the access of patients that live furthest from Lisbon would not be possible without affecting other ongoing therapies. The vast majority of patients (94.1\%) sent to this center for HBOT came from other hospitals. This fact limited our access to relevant data contained in their clinical reports.

In this review, and in accordance with literature, there was an increased incidence of Fournier's gangrene in males in their sixth decade of life..$^{2-4}$

The most frequent etiology was urinary tract conditions $(38.9 \%)$ followed by anorectal and colon pathologies $(27.8 \%)$. These distributions are similar to results obtained in other previous studies. ${ }^{1,6}$

Considering microbiological agents usually participating in this type of infections, treatment strategy involves combining broad spectrum antibiotics covering gram- positive, gram-negative and anaerobes. Since Fournier's gangrene is an acute and rapidly progressive disease, antibiotics are started expeditiously and empirically, in some cases this takes precedence over collecting material to microbiological testing, which may affect the results. In this work only 4 patients had microbiological results, it was admitted that former antibiotherapy approach and missing information in clinical records may have influenced our search.

Large spectrum antibiotherapy was applied in several combinations, always considering anaerobials, as observed by many works. ${ }^{1,8}$

The number of sessions varied considerably, possibly due to the two distinct therapeutic approaches. On the one hand performing HBOT until achievement of control of acute clinical features, what usually happens in the first week, and, on the other hand, ongoing HBOT in the following weeks to promote wound healing, ${ }^{10}$ which can significantly increase the number of needed sessions.

Similarly to previous studies, the most common observed comorbidity was diabetes $(61.9 \%$ of patients who had comorbidities), suggesting that diabetes is one of the predisposing factors for necrotizing fasciitis and Fournier's gangrene. $1,6,15,16$

Although the majority of deceased patients had diabetes (4 out of 5), no significant correlation between diabetes as comorbidity and death was found.

In recent studies, it was found that Fournier's gangrene mortality rate ranges between $16 \%^{4}$ to $30.8 \%{ }^{17}$, namely $17.6 \%^{13}$ in patients that underwent HBOT. Similarly, in our review, a mortality rate of $20.8 \%$.was observed. 


\section{CONCLUSIONS}

Although Fournier's gangrene is a rare condition, it is nevertheless a fatal illness, namely in patients with comorbidities like diabetes, and as such it should remain a subject of study so that its treatment is optimized.

The cornerstone of treatment remains early recognition, prompt surgical debridement, broad-spectrum antibiotherapy and aggressive supportive care.

HBOT is strongly recommended as an adjuvant treatment in necrotizing soft tissue infections in the acute phase and can also be used to promote wound healing, and thus should be considered whenever available.

To further assess the role of HBOT in the treatment of this condition, additional studies should be carried out.

\section{PROTECTION OF HUMANS AND ANIMALS}

The authors declare that the procedures were followed according to the regulations established by the Clinical Research and Ethics Committee and to the Helsinki Declaration of the World Medical Association.

\section{DATA CONFIDENTIALITY}

The authors declare having followed the protocols in use at their working center regarding patient's data publication.

\section{CONFLICTS OF INTEREST}

The authors state no conflict of interests and have received no payment to perform this work.

\section{FUNDING SOURCES}

No subsidies or grants contributed to this work.

\section{REFERENCES}

1. Sarani B, Strong M, Pascual J, Schwab CW. Necrotizing fasciitis: current concepts and review of the literature. J Am Coll Surg. 2009;208:279-88.

2. Shyam DC, Rapsang AG. Fournier's gangrene. Surgeon. 2013;11:22232.

3. Sorensen MD, Krieger JN, Rivara FP, Broghammer JA, Klein MB, Mack $C D$, et al. Fournier's gangrene: population based epidemiology and outcomes. J Urol. 2009;181:2120-6.

4. Eke N. Fournier's gangrene: a review of 1726 cases. $\mathrm{Br} \mathrm{J}$ Surg. 2000:718-28.

5. Torremadé Barreda J, Millán Scheiding $M$, Suárez Fernández $C$ Cuadrado Campaña JM, Rodríguez Aguilera J, Franco Miranda E, et al. Fournier gangrene. A retrospective study of 41 cases. Cir Esp. (English Ed). 2010;87:218-23.

6. Cardoso JB, Féres O. Grangena de Fournier. Medicina. 2007;40:493-9.

7. Sroczyński M, Sebastian M, Rudnicki J, Sebastian A, Agrawal AK. A complex approach to the treatment of Fournier's gangrene. Adv Clin Exp Med. 2013:131-5.

8. Hakkarainen TW, Kopari NM, Pham TN, Evans HL. Necrotizing soft tissue infections: review and current concepts in treatment, systems of care, and outcomes. Curr Probl Surg. 2014;51:344-62.

9. Goulon M, Bakker D, Marroni A, Mathieu D, Wattel F, Bitterman N. $7^{\text {th }}$ European Consensus Conference on Hyperbaric Medicine. In: $7^{\text {th }}$ European Consensus Conference on Hyperbaric Medicine. Lille:
European Committee for Hyperbaric Medicine; 2004. p.1-20.

10. Mathieu D, editor. Handbook on Hyperbaric Medicine. Amsterdam: Springer; 2006.

11. Albuquerque G, Sousa J. Oxigénio e medicina subaquática e hiperbárica. Perspectiva Histórica E Realidade Militar Em Portugal. In: Cadernos Navais. Lisboa: Edições Culturais da Marinha; 2011. p. 125-7.

12. Shaw JJ, Psoinos C, Emhoff TA, Shah SA, Santry HP. Not just full of hot air: hyperbaric oxygen therapy increases survival in cases of necrotizing soft tissue infections. Surg Infect. 2014;15:328-35.

13. Lind F, Öhlén G, Lindén V, Eriksson BM, Frostell C. Focus Report Treatment with Hyperbaric Oxygen (HBO) at the Karolinska University Hospital. Stockholm: Karolinska University Hospital; 2011.

14. Soh C, Pietrobon R, Freiberger J, Chew S. Hyperbaric oxygen therapy in necrotising soft tissue infections: a study of patients in the United States Nationwide Inpantient Sample. Intensive Care Med. 2012;38:1143-51.

15. Nisbet AA, Thompson IM. Impact of diabetes mellitus on the presentation and outcomes of Fournier's gangrene. Urology. 2002;60:775-9.

16. Korkut M, Içoz G, Dayangac M, Akgun E, Yentay L, Erdogan O. Outcome analysis in patients with Fournier's gangrene. Dis Colon Rectum. 2003;46:649-52.

17. Corrêa Neto IJ, Sia ON, Rolim AS, Souza RF, Watté HH; Robles L. Clinical outcomes of Fournier's gangrene from a tertiary hospital. J Coloproctology. 2012;32:407-10. 
Isabel ROSA, Francisco GUERREIRO

\section{Hyperbaric Oxygen Therapy for the Treatment of Fournier's Gangrene: A Review of 34 Cases}

Acta Med Port 2015:28:619-623

Publicado pela Acta Médica Portuguesa, a Revista Científica da Ordem dos Médicos

Av. Almirante Gago Coutinho, 151

1749-084 Lisboa, Portugal.

Tel: +351218428 215

E-mail: submissao@actamedicaportuguesa.com

www.actamedicaportuguesa.com

ISSN:0870-399X | e-ISSN: 1646-0758

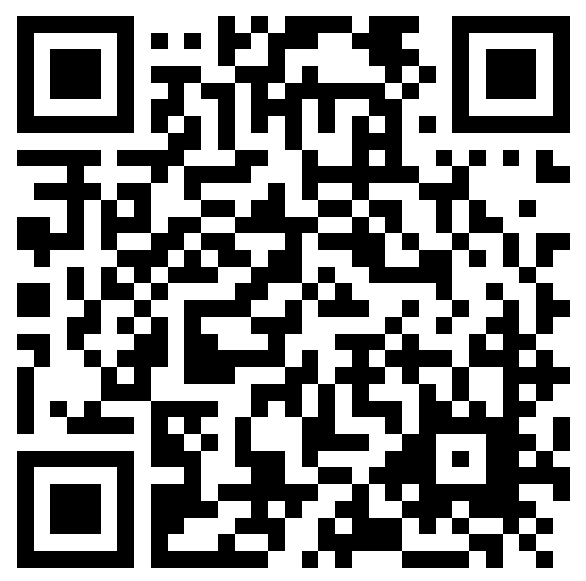

